\title{
PENJADWALAN ROTASI DAERAH IRIGASI SIMANDOLAK II KABUPATEN KUANTAN SINGINGI
}

\author{
Ririn Rindayani ${ }^{1}$, Manyuk Fauzi ${ }^{2}$, Rinaldi $^{3}$ \\ Program Studi S1 Teknik Sipil, Fakultas Teknik, Universitas Riau \\ Kampus Bina Widya J. HR Soebrantas KM 12,5 Pekanbaru, Kode Pos 28293 \\ Email : ririn.rindayani@student.unri.ac.id, manyuk.fauzi@unri.ac.id, ri.naldi@yahoo.com
}

\begin{abstract}
ABSTRAK
Daerah irigasi Simandolak II Kabupaten Kuantan Singingi dengan luas lahan irigasi 690,10 Ha memerlukan manajemen sistem pemberian dan pembagian air sebagai solusi kekurangan air untuk mencukupi kebutuhan air irigasi. Rencana tata tanam dengan meningkatkan intensitas tanam menggunakan dua sistem, yaitu pemberian air dengan luasan total dan penggolongan. Kejadian deficit pada pembagian air dengan menggunakan sistem pemberian luasan total lebih banyak dibandingkan sistem penggolongan yaitu pada bulan November periode 1 sebesar 1,40 $\mathrm{m}^{3} / \mathrm{dt}$. Evaluasi ketersediaan air menggunakan faktor K yaitu K=1. Rotasi pembagian air irigasi dilakukan berdasarkan kondisi deficit pada neraca air setelah penggolongan dengan kejadian terbanyak pada pola tanam padi-padi-padi dengan 8 kejadian. Rotasi ditekankan pada pemenuhan untuk beberapa petak dalam satu golongan kemudian dirotasikan kepetak dan golongan lain sesuai jadwal pemberian air pada masa pertumbuhan tanaman dengan periode gilir selama 15 harian. Persentase peningkatan volume rotasi terbesar terjadi pada Simandolak II MT III untuk pola tanam padi-padi-padi sebesar $66 \%$.
\end{abstract}

Kata Kunci: irigasi, intensitas tanam, sistem luasan total, sistem penggolongan, rotasi

\begin{abstract}
The Simandolak II irrigation area in Kabupaten Kuantan Singingi with an irrigated land area of 690,10 Ha requires a management system for the supply and distribution of water as a solution to lack of water to meet irrigation water needs. Planting plan by increasing cropping intensity using two systems, that is the distribution of water with total area and classification. The occurrence of deficits in the distribution of water using a system of giving a total area more than the classification system, that is in November first period amounted to $1,40 \mathrm{~m}^{3} / \mathrm{sec}$. Evaluation of water availability uses the $K$ factor, $K=1$. Rotation of irrigation water distribution was carried out based on deficit conditions on the water balance after classification with the highest incidence in paddy-paddy-paddy cropping patterns with 8 events. Rotation is emphasized in the fulfillment of several plots in one group then rotated into plots and other groups according to the schedule of water supply during the period of plant growth with a turn period of 15 days. The percentage increase in the volume of the largest rotation of occurred on Simandolak II MT III planting pattern to paddy-paddy-paddy amounting to $66 \%$.
\end{abstract}

Keywords: irrigation, planting intensity, total area system, classification system, rotation.

\section{PENDAHULUAN}

Indonesia merupakan negara yang strategis. Sisi geografis Indonesia termasuk dalam daerah beriklim tropis dengan karakteristik tingkat curah hujan yang tinggi. Meskipun terletak di kawasan beriklim tropis dengan karakteristik hujan yang tinggi, kawasan beriklim tropis juga megalami saat dimana hujan tidak selalu ada atau musim kemarau. Menanggapi kodisi tersebut diperlukan suatu sistem yang dapat menyediakan, membagikan, mengelola dan mengatur air untuk meningkatkan produksi lahan pertanian [4].

Khusus pada sektor pertanian, curah hujan dijadikan parameter penentu ketersediaan air bagi tanaman. Tingkat kebutuhan air bervariasi tergantung pada jenis tanamannya. Tujuan pola tanam adalah untuk menghindari ketidakseragaman tanaman sehingga waktu tanam dapat dilakukan sesuai jadwal dan meningkatkan efisiensi serta produksi irigasi. Pola tanam yang berbeda juga berdampak pada penjadwalan pemberian airnya. Umumnya untuk 
tanaman padi metode yang digunakan untuk pemberian air adalah pemberian air dengan sistem terputus putus, pemberian air secara terus menerus, atau dengan sistem rotasi penggolongan.

[5] Daerah Irigasi (DI) Kelingi, Sumatera Selatan memiliki permasalahan dimana DI ini awalnya ditujukan hanya untuk penanaman padi. Seiring perkembangan, beberapa bagian lahan beralih fungsi tidak hanya untuk pertanian tetapi untuk perkebunan dan kolam ikan. Hal ini berdampak pada permasalahan kekurangan air untuk memenuhi irigasi pertanian. DI Simandolak II memiliki potensi permasalahan yang sama dengan apa yang terjadi pada DI Kelingi, Sumatera Selatan. Sehingga perlu dilakukan penelitian lebih lanjut mengenai sistem pemberian dan pembagian air untuk mencukupi kebutuhan air irigasi di daerah tersebut.

Simandolak II berlokasi di Kabupaten Kuantan Singingi dengan luas lahan sebesar 690,10 Ha. Untuk memperoleh tanaman dengan pertumbuhan yang optimal guna mencapai produktifitas tinggi, maka penanaman harus memperhatikan pembagian air secara merata keseluruh petak dalam jaringan irigasi. Sumber air tidak selalu dapat menyediakan air irigasi yang dibutuhkan, sehingga harus dibuat rencana pembagian air yang baik, agar air yang tersedia dapat digunakan secara merata dan seadil-adilnya.

Penelitian ini bertujuan untuk mengevaluasi sistem pemberian dan pembagian air irigasi kondisi serta merencanakan rotasi irigasi berdasarkan imbang antara ketersediaan dan kebutuhan irigasi dalam rangka meningkatkan intensitas tanam dan produktifitas pertanian.

\section{METODE PENELITIAN}

\subsection{Lokasi Penelitian}

DI Simandolak II merupakan bagian dari DI Simandolak-Pangean yang berada dibawah kewenangan pemerintah dengan luas layanan sekitar 690,10 Ha berdasarkan data sekunder. DI Simandolak II mendapatkan sumber air untuk keperluan irigasi dari Sungai Pulo Loeh yang dibendung oleh Bendung Simandolak II. Bendung ini berada pada Kecamatan Sentajo Raya dengan Koordinat $0^{\circ} 24^{\prime} 12.54 " S$ dan $101^{\circ} 37^{\prime} 50.87^{\prime \prime E}$. Sumber air DI Simandolak II berasal dari Sei Pulo Loeh yang melayani irigasi 2 desa, yaitu desa Jalur Patah di Kecamatan Sentajo Raya dan Desa Rawang Binjai di Kecamatan Pangean. Luas DAS untuk Simandolak II yaitu sebesar 50,664 $\mathrm{Km}^{2}$. Sementara untuk luas DAS AWLR Pulau Berhalo yaitu $7467 \mathrm{Km}^{2}$ yang diperoleh dari BWS Sumatera III.

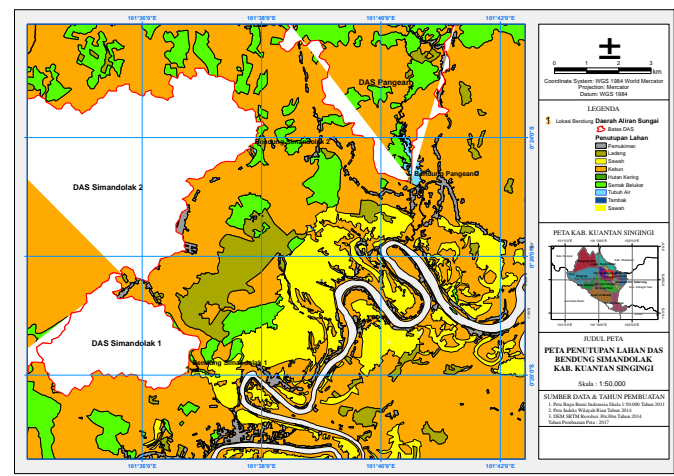

Gambar 1 Peta penutupan lahan di wilayah DI Simandolak II [2]

Penggunaan lahan di wilayah studi di dominasi oleh areal perkebunan, hutan sekunder dan semak belukar. Lahan pertanian pada umumnya berada di sepanjang aliran sungai Kuantan (Indragiri).

\subsection{Pengumpulan Data}

Data yang dikumpulkan terdiri dari :

1. Kondisi eksisting DI SimandolakII , meliputi:

a. Skema dan luas areal sawah

b. Kebutuhan air kondisi luasan total (eksisting)

2. Data hidrologi, meliputi :

a. Debit DI Simandolak II berdasarkan data AWLR Pulau Berhalo selama 9 tahun

b. Data Curah hujan Stasiun Hujan Sentajo selama 10 tahun

c. Data Klimatologi Stasiun Sentajo selama 10 tahun

\subsection{Analisa Data}

1. Analisa Ketersediaan Air

a. Curah Hujan Efektif

Perhitungan curah hujan efektif menggunakan Metode Ranking Weibull

b. Debit Andalan

Perhitungan debit andalan menggunakan Metode Analisa Regional

2. Analisa Kebutuhan Air

Kebutuhan air dihitung berdasarkan Standar Perencanaan Irigasi Jaringan Irigasi (KP-01). Variabel masukan analisa kebutuhan air diantaranya data klimatologi, evapotranspirasi potensial.

3. Rencana Pola Tanam

Pola tanam rencana ditujukan untuk meningkatkan intensitas tanam dan meningkatkan produktifitas tanam dengan mempertimbangkan kebiasaan dan kebijakan wilayah setempat.

4. Neraca Air

Neraca air atau imbang air berupa nilai ketersediaan air dikurangi kebutuhan air perperiode setengah bulanan untuk setiap pola tanam. Nilai ini digunakan untuk mengetahui 
ketersediaan air di lokasi dalam mencukupi kebutuhan irigasi. Sehingga nantinya dapat dipilih sistem pemberian air yang sesuai.

5. Rotasi

Pengaturan penggiliran pada DI Simandolak II dibagi dalam 3 golongan. Perhitungan penjadwalan rotasi irigasi didasarkan pada faktor $\mathrm{K}$ yang diperoleh dari nilai ketersediaan dibagi kebutuhan.

Alur pengerjaan studi dapat dilihat pada bagan alir berikut:

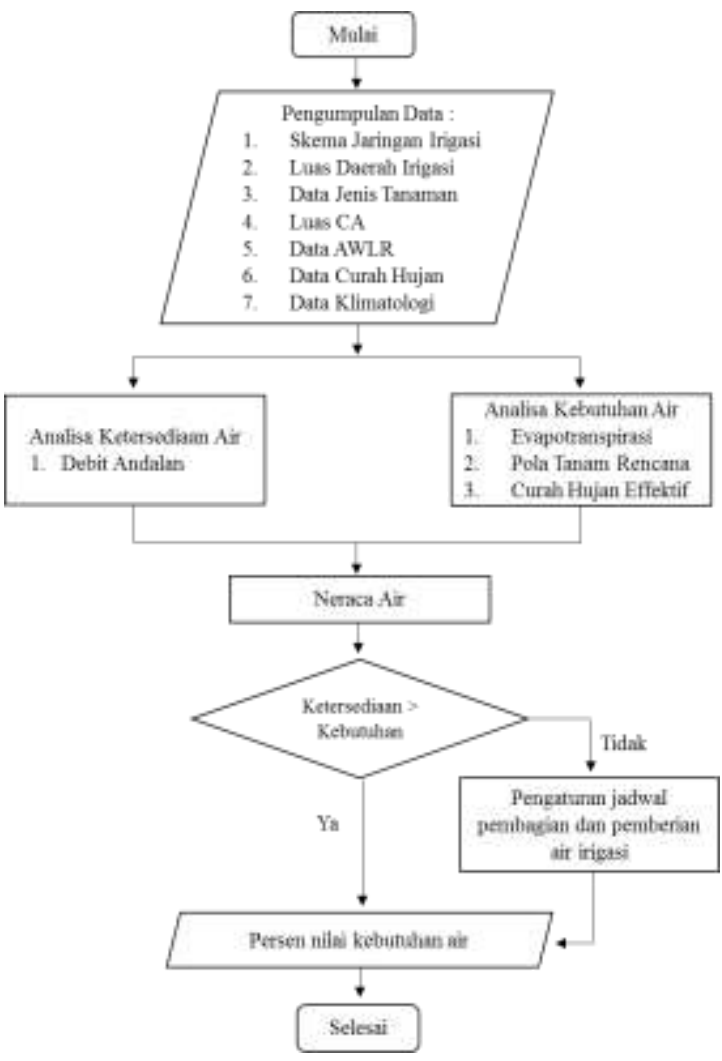

Gambar 2 Bagan alir penelitian

\section{HASIL DAN PEMBAHASAN}

\subsection{Curah Hujan Efektif}

Curah hujan efektif merupakan curah hujan yang turun diderah irigasi dan dapat langsung dimanfaatkan dalam memenuhi kebutuhan tanaman. Perhitungan curah hujan efektif didapat dari nilai curah hujan bulanan dari stasiun pencatat hujan.. Curah hujan efektif yang diperlukan adalah $70 \%$ dari curah hujan setengah bulanan terlampaui yang bergantung pada jenis budidaya tanaman yang ditanam

Tanaman padi

Tanaman palawija

$$
\mathrm{Re}=\frac{1}{15} \times 70 \% \times \mathrm{R}_{80}
$$

$$
\mathrm{Re}=\frac{1}{15} \times 70 \% \times \mathrm{R}_{50}
$$

Hasil perhitungan curah hujan efektif untuk padi dan palawija dapat dilihat pada Tabel 1

\begin{tabular}{|c|c|c|c|c|c|c|}
\hline \multirow{3}{*}{ No } & \multirow{3}{*}{ Bulan } & \multirow{3}{*}{ Periode } & \multicolumn{2}{|c|}{ Padi } & \multicolumn{2}{|c|}{ Palawija } \\
\hline & & & $\mathrm{R} 80$ & $\mathrm{Re}$ & R50 & $\mathrm{Re}$ \\
\hline & & & (mm/hari) & (mm/hari) & (mm/hari) & (mm/hari) \\
\hline \multirow{2}{*}{1} & \multirow{2}{*}{ Januari } & I & 18,50 & 0,86 & 45,90 & 2,14 \\
\hline & & II & 57,50 & 2,52 & 177,60 & 7,77 \\
\hline \multirow{2}{*}{2} & \multirow{2}{*}{ Februari } & I & 56,00 & 2,61 & 99,00 & 4,62 \\
\hline & & II & 47,00 & 2,53 & 130,90 & 7,05 \\
\hline \multirow{2}{*}{3} & \multirow{2}{*}{ Maret } & I & 64,50 & 3,01 & 101,10 & 4,72 \\
\hline & & II & 70,90 & 3,10 & 199,60 & 8,73 \\
\hline \multirow{2}{*}{4} & \multirow{2}{*}{ April } & I & 55,60 & 2,59 & 107,00 & 4,99 \\
\hline & & II & 82,00 & 3,83 & 125,40 & 5,85 \\
\hline \multirow{2}{*}{5} & \multirow{2}{*}{ Mei } & I & 61,60 & 2,87 & 96,40 & 4,50 \\
\hline & & II & 44,30 & 1,94 & 75,80 & 3,32 \\
\hline \multirow{2}{*}{6} & \multirow{2}{*}{ Juni } & I & 15,00 & 0,70 & 44,00 & 2,05 \\
\hline & & II & 35,10 & 1,64 & 52,00 & 2,43 \\
\hline \multirow{2}{*}{7} & \multirow{2}{*}{ Juli } & I & 25,00 & 1,17 & 51,30 & 2,39 \\
\hline & & II & 12,30 & 0,54 & 66,30 & 2,90 \\
\hline \multirow{2}{*}{8} & \multirow{2}{*}{ Agustus } & I & 13,80 & 0,64 & 42,50 & 1,98 \\
\hline & & II & 49,20 & 2,15 & 86,90 & 3,80 \\
\hline \multirow{2}{*}{9} & \multirow{2}{*}{ September } & I & 49,00 & 2,29 & 75,90 & 3,54 \\
\hline & & II & 44,90 & 2,10 & 93,80 & 4,38 \\
\hline \multirow{2}{*}{10} & \multirow{2}{*}{ Oktober } & I & 62,20 & 2,90 & 100,40 & 4,69 \\
\hline & & II & 46,00 & 2,01 & 59,00 & 2,58 \\
\hline \multirow{2}{*}{11} & \multirow{2}{*}{ November } & I & 47,60 & 2,22 & 106,20 & 4,96 \\
\hline & & II & 62,60 & 2,92 & 164,90 & 7,70 \\
\hline \multirow{2}{*}{12} & \multirow{2}{*}{ Desember } & I & 39,00 & 1,82 & 60,20 & 2,81 \\
\hline & & II & 26,50 & 1,16 & 120,50 & 5,27 \\
\hline
\end{tabular}

Tabel 1 Curah hujan efektif Stasiun Sentajo

\subsection{Debit Andalan}

Debit andalan adalah debit minimum sungai yang tersedia untuk memenuhi kebutuhan irigasi [6]. [1] Perhitungan ketersediaan air dilakukan untuk mengetahui air yang tersedia dari sumber utama air irigasi untuk memenuhi kebutuhan air irigasi yang direncanakan.

Bila data debit pada setiap titik sampul atau node dari sistem tata air tidak tersedia maka untuk estimasi besarnya debit yang tersedia di masingmasing lokasi dapat menggunakan Metode Analisa Regional. Metode ini digunakan untuk membangkitkan data debit di masing-masing lokasi pemanfaatan SDA berdasarkan data dari pos pencatatan debit dengan panjang seri data $\geq 10$ thn dan berada pada DAS atau WS yang sama. Metode ini membandingkan luas catchment area dengan mempertimbangkan besarnya nilai rata-rata curah hujan persub DAS dengan pendekatan sebagai berikut :

$$
\begin{aligned}
& \mathrm{Q}=\frac{\mathrm{CA} A_{E C}}{C_{P D A}} \times \frac{M_{P A R_{E C}}}{M_{P A}} \times Q_{P D A} \\
& Q=Q_{E C}+Q_{P D A}
\end{aligned}
$$

dengan :

$\mathrm{Q}_{\mathrm{EC}} \quad=$ Debit pada Sub-DAS yang akan dihitung (DAS antara titik E dan C) 
$\mathrm{CA}_{\mathrm{Ec}}=$ Luas catchment area Sub-DAS yang akan dihitung

MAREC $_{E}=$ Curah hujan rata-rata tahunan didaerah Sub-DAS yang akan dihitung

QPDA $=$ Debit bulanan pada lokasi pos duga air

$\mathrm{CA}_{\mathrm{PDA}}=$ Luas catchment area pada lokasi pos duga air

MARPDA $_{\text {PDA }}$ Curah hujan rata-rata tahunan di catchment area pos duga air

Tot $\mathrm{Q}_{\mathrm{c}}=$ Debit pada titik $\mathrm{C}$

Hasil perhitungan debit andalan dengan menggunakan Metode Analisa Regional untuk tiap DI periode setengah bulanan dapat dilihat pada Tabel 2

Tabel 2 Debit andalan Simandolak II

\begin{tabular}{|c|c|c|c|c|c|c|c|}
\hline No & Bulan & Periode & $\begin{array}{l}\text { Q 80\% } \\
\text { (m3/dt) }\end{array}$ & No & Bulan & Periode & $\begin{array}{l}\text { Q 80\% } \\
\text { (m3/dt) }\end{array}$ \\
\hline \multirow{2}{*}{1} & \multirow{2}{*}{ Jan } & I & 1,74 & \multirow{2}{*}{7} & \multirow{2}{*}{ Jul } & I & 0,56 \\
\hline & & II & 1,33 & & & II & 0,55 \\
\hline \multirow{2}{*}{2} & \multirow{2}{*}{ Feb } & I & 1,24 & \multirow{2}{*}{8} & \multirow{2}{*}{ Agust } & I & 0,54 \\
\hline & & II & 1,05 & & & II & 0,69 \\
\hline \multirow{2}{*}{3} & \multirow{2}{*}{ Mar } & I & 0,84 & \multirow{2}{*}{9} & \multirow{2}{*}{ Sep } & I & 0,66 \\
\hline & & II & 1,01 & & & II & 0,63 \\
\hline \multirow{2}{*}{4} & \multirow{2}{*}{ Apr } & I & 1,00 & \multirow{2}{*}{10} & \multirow{2}{*}{ Okt } & I & 0,57 \\
\hline & & II & 1,39 & & & II & 1,22 \\
\hline \multirow{2}{*}{5} & \multirow{2}{*}{ Mei } & I & 1,18 & \multirow{2}{*}{11} & \multirow{2}{*}{ Nop } & I & 2,07 \\
\hline & & II & 0,88 & & & II & 1,97 \\
\hline \multirow{2}{*}{6} & \multirow{2}{*}{ Jun } & I & 0,77 & \multirow{2}{*}{12} & \multirow{2}{*}{ Des } & I & 1,23 \\
\hline & & II & 0,64 & & & II & 1,41 \\
\hline
\end{tabular}

\subsection{Pola Tanam Rencana}

Pola tanam merupakan sistem dalam penentuan jenis tanaman yang sesuai dengan persediaan air pada periode musim kemarau dan musim penghujan. Tujuan dari penentuan pola tanam, yaitu :
a. Menghindari ketidakseragaman tanaman
b. Melaksanakan waktu tanam sesuai jadwal
c. Efisiensi irigasi
d. Meningkatkan faktor produksi pangan

Jenis pola tanam yang digunakan pada penelitian ini yaitu padi-bera-bera dan padi-padipadi.

\subsection{Kondisi Total Luasan}

Perhitungan kebutuhan air pada irigasi dilakukan dengan menggunakan total luasan tiap petak sawah untuk melihat apakah diperlukan penggolongan dan rotasi pebagian serta pemberian air irigasi untuk DI Simandolak II

Perhitungan evaluasi menggunakan kondisi eksisting di wilayah studi dengan total luasan DI Simandolak II yaitu 690,10 Ha

\subsection{Kebutuhan Air Kondisi Luasan Total}

Rekapitulasi kebutuhan air untuk tiap DI dan pola tanam kondisi luasan total dapat dilihat pada Tabel 3 dan Tabel 4
Tabel 3 Kebutuhan air kondisi luasan total pola tanam padi-bera-bera

\begin{tabular}{|c|c|c|c|c|c|c|c|}
\hline No & Bulan & Periode & $\begin{array}{l}\text { Kebutuhan } \\
\text { Air (m3/dt) }\end{array}$ & No & Bulan & Periode & $\begin{array}{l}\text { Kebutuhan } \\
\text { Air (m3/dt) }\end{array}$ \\
\hline \multirow{2}{*}{1} & \multirow{2}{*}{ Nov } & I & 1,40 & \multirow{2}{*}{7} & \multirow{2}{*}{ Mei } & I & 0,00 \\
\hline & & II & 1,31 & & & II & 0,00 \\
\hline \multirow{2}{*}{2} & \multirow{2}{*}{ Des } & I & 0,76 & \multirow{2}{*}{8} & \multirow{2}{*}{ Jun } & I & 0,00 \\
\hline & & II & 0,83 & & & II & 0,00 \\
\hline \multirow{2}{*}{3} & \multirow{2}{*}{ Jan } & I & 0,85 & \multirow{2}{*}{9} & \multirow{2}{*}{ Jul } & I & 0,00 \\
\hline & & II & 0,62 & & & II & 0,00 \\
\hline \multirow{2}{*}{4} & \multirow{2}{*}{ Feb } & I & 0,17 & \multirow{2}{*}{10} & \multirow{2}{*}{ Agu } & I & 0,00 \\
\hline & & II & 0,00 & & & II & 0,00 \\
\hline \multirow{2}{*}{5} & \multirow{2}{*}{ Mar } & I & 0,00 & \multirow{2}{*}{11} & \multirow{2}{*}{ Sep } & I & 0,00 \\
\hline & & II & 0,00 & & & II & 0,00 \\
\hline \multirow{2}{*}{6} & \multirow{2}{*}{ Apr } & I & 0,00 & \multirow{2}{*}{12} & \multirow{2}{*}{ Okt } & I & 0,00 \\
\hline & & II & 0,00 & & & II & 0,00 \\
\hline
\end{tabular}

Tabel 4 Kebutuhan air kondisi luasan total pola tanam padi-padi-padi

\begin{tabular}{|c|c|c|c|c|c|c|c|}
\hline No & Bulan & Periode & $\begin{array}{l}\text { Kebutuhan } \\
\text { Air (m3/dt) }\end{array}$ & No & Bulan & Periode & $\begin{array}{l}\text { Kebutuhan } \\
\text { Air (m3/dt) }\end{array}$ \\
\hline \multirow{2}{*}{1} & \multirow{2}{*}{ Nov } & I & 1,40 & \multirow{2}{*}{7} & \multirow{2}{*}{ Mei } & I & 0,58 \\
\hline & & II & 1,31 & & & II & 0,67 \\
\hline \multirow{2}{*}{2} & \multirow{2}{*}{ Des } & I & 0,76 & \multirow{2}{*}{8} & \multirow{2}{*}{ Jun } & I & 0,36 \\
\hline & & II & 0,83 & & & II & 0,04 \\
\hline \multirow{2}{*}{3} & \multirow{2}{*}{ Jan } & I & 0,85 & \multirow{2}{*}{9} & \multirow{2}{*}{ Jul } & I & 1,28 \\
\hline & & II & 0,62 & & & II & 1,36 \\
\hline \multirow{2}{*}{4} & \multirow{2}{*}{ Feb } & I & 0,17 & \multirow{2}{*}{10} & \multirow{2}{*}{ Agu } & I & 0,90 \\
\hline & & II & 0,00 & & & II & 0,70 \\
\hline \multirow{2}{*}{5} & \multirow{2}{*}{ Mar } & I & 1,08 & \multirow{2}{*}{11} & \multirow{2}{*}{ Sep } & I & 0,68 \\
\hline & & II & 1,07 & & & II & 0,68 \\
\hline \multirow{2}{*}{6} & \multirow{2}{*}{ Apr } & I & 0,60 & \multirow{2}{*}{12} & \multirow{2}{*}{ Okt } & I & 0,14 \\
\hline & & II & 0,44 & & & II & 0,00 \\
\hline
\end{tabular}

\subsection{Neraca Air Kondisi Luasan Total}

Neraca air atau imbang air berupa nilai ketersediaan air dikurangi kebutuhan air pada setiap DI perperiode setengah bulanan untuk setiap pola tanam. Hasil analisa neraca air dapat dilihat pada Tabel 5 dan Tabel 6, sementara grafik neraca untuk kedua pola tanam dapat dilihat pada Gambar 3 dan 4

$\underline{\text { Tabel } 5 \text { Neraca air pola tanam padi-bera-bera }}$

\begin{tabular}{|c|c|c|c|c|c|c|c|c|}
\hline Bulan & Periode & MT & $\begin{array}{c}\text { Kebutuhan } \\
\text { m3/dt }\end{array}$ & $\begin{array}{c}\text { Ketersediaan Air Q } \\
\text { Andalan 80\% } \\
\text { m3/dt }\end{array}$ & Imbang Air & Kondisi & Faktor $\mathrm{K}$ & $\begin{array}{l}\text { Rata-rata } \\
\text { Faktor K }\end{array}$ \\
\hline \multirow{2}{*}{ November } & 1 & \multirow{8}{*}{ MT 1} & 1,40 & & 0,67 & Surplus & 1,00 & \multirow{8}{*}{1,00} \\
\hline & 2 & & 1,31 & 1,97 & 0,66 & Surplus & 1,00 & \\
\hline \multirow{2}{*}{ Desember } & 1 & & 0,76 & 1,23 & 0,47 & Surplus & 1,00 & \\
\hline & 2 & & 0,83 & 1,41 & 0,59 & Surplus & 1,00 & \\
\hline \multirow{2}{*}{ Januari } & 1 & & 0,85 & 1,74 & 0,89 & Surplus & 1,00 & \\
\hline & 2 & & 0,62 & 1,33 & 0,71 & Surplus & 1,00 & \\
\hline \multirow{2}{*}{ Februari } & 1 & & 0,17 & 1,24 & 1,08 & Surplus & 1,00 & \\
\hline & 2 & & 0,00 & 1,05 & 1,05 & Surplus & 1,00 & \\
\hline \multirow{2}{*}{ Maret } & 1 & \multirow{8}{*}{ MT 2} & 0,00 & 0,84 & 0,84 & Surplus & 1,00 & \multirow{8}{*}{1,00} \\
\hline & 2 & & 0,00 & 1,01 & 1,01 & Surplus & 1,00 & \\
\hline \multirow{2}{*}{ April } & 1 & & 0,00 & 1,00 & 1,00 & Surplus & 1,00 & \\
\hline & 2 & & 0,00 & 1,39 & 1,39 & Surplus & 1,00 & \\
\hline \multirow{2}{*}{ Mei } & 1 & & 0,00 & 1,18 & 1,18 & Surplus & 1,00 & \\
\hline & 2 & & 0,00 & 0,88 & 0,88 & Surplus & 1,00 & \\
\hline \multirow{2}{*}{ Juni } & 1 & & 0,00 & 0,77 & 0,77 & Surplus & 1,00 & \\
\hline & 2 & & 0,00 & 0,64 & 0,64 & Surplus & 1,00 & \\
\hline \multirow{2}{*}{ Juli } & 1 & & 0,00 & 0,56 & 0,56 & Surplus & 1,00 & \multirow{8}{*}{1,00} \\
\hline & 2 & & 0,00 & 0,55 & 0,55 & Surplus & 1,00 & \\
\hline \multirow{2}{*}{ Agustus } & 1 & & 0,00 & 0,54 & 0,54 & Surplus & 1,00 & \\
\hline & 2 & & 0,00 & 0,69 & 0,69 & Surplus & 1,00 & \\
\hline \multirow{2}{*}{ September } & 1 & MT 3 & 0,00 & 0,66 & 0,66 & Surplus & 1,00 & \\
\hline & 2 & & 0,00 & 0,63 & 0,63 & Surplus & 1,00 & \\
\hline \multirow{2}{*}{ Oktober } & 1 & & 0,00 & 0,57 & 0,57 & Surplus & 1,00 & \\
\hline & 2 & & 0,00 & 1,22 & 1,22 & Surplus & 1,00 & \\
\hline
\end{tabular}




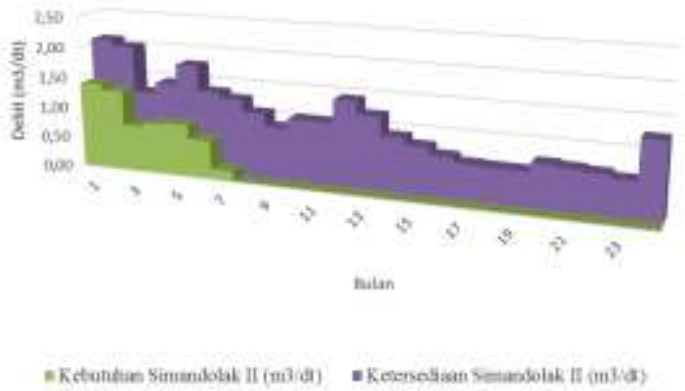

Gambar 3 Grafik Neraca Air Pola Tanam Padi-bera-bera

Tabel 6 Neraca air pola tanam padi-padi-padi

\begin{tabular}{|c|c|c|c|c|c|c|c|c|}
\hline Bulan & Periode & MT & $\begin{array}{c}\text { Kebutuhan } \\
\text { m3/dt }\end{array}$ & $\begin{array}{c}\text { Ketersediaan Air Q } \\
\text { Andalan 80\% } \\
\text { m3/dt }\end{array}$ & $\begin{array}{c}\text { Imbang } \\
\text { Air }\end{array}$ & Kondisi & Faktor K & $\begin{array}{l}\text { Rata-rata } \\
\text { Faktor } \mathrm{K}\end{array}$ \\
\hline \multirow{2}{*}{ November } & 1 & \multirow{8}{*}{ I } & 1,40 & 2,07 & 0,67 & Surplus & 1,00 & \multirow{8}{*}{1,00} \\
\hline & 2 & & 1,31 & 1,97 & 0,66 & Surplus & 1,00 & \\
\hline \multirow{2}{*}{ Desember } & 1 & & 0,76 & 1,23 & 0,47 & Surplus & 1,00 & \\
\hline & 2 & & 0,83 & 1,41 & 0,59 & Surplus & 1,00 & \\
\hline \multirow{2}{*}{ Januari } & 1 & & 0,85 & 1,74 & 0,89 & Surplus & 1,00 & \\
\hline & 2 & & 0,62 & 1,33 & 0,71 & Surplus & 1,00 & \\
\hline \multirow{2}{*}{ Februari } & 1 & & 0,17 & 1,24 & 1,08 & Surplus & 1,00 & \\
\hline & 2 & & 0,00 & 1,05 & 1,05 & Surplus & 1,00 & \\
\hline \multirow{2}{*}{ Maret } & 1 & \multirow{8}{*}{ II } & 1,08 & 0,84 & $-0,24$ & Deficit & 0,78 & \multirow{8}{*}{0,96} \\
\hline & 2 & & $\begin{array}{l}1,07 \\
\end{array}$ & 1,01 & $-0,06$ & Deficit & 0,94 & \\
\hline \multirow{2}{*}{ April } & 1 & & 0,60 & 1,00 & 0,40 & Surplus & 1,00 & \\
\hline & 2 & & 0,44 & 1,39 & 0,95 & Surplus & 1,00 & \\
\hline \multirow{2}{*}{ Mei } & 1 & & 0,58 & 1,18 & 0,60 & Surplus & 1,00 & \\
\hline & 2 & & 0,67 & 0,88 & 0,21 & Surplus & 1,00 & \\
\hline \multirow{2}{*}{ Juni } & 1 & & 0,36 & 0,77 & 0,41 & Surplus & 1,00 & \\
\hline & 2 & & 0,04 & 0,64 & 0,60 & Surplus & 1,00 & \\
\hline \multirow{2}{*}{ Juli } & 1 & & 1,28 & 0,56 & $-0,72$ & Deficit & 0,44 & \multirow{8}{*}{0,79} \\
\hline & 2 & & 1,36 & 0,55 & $-0,81$ & Deficit & 0,40 & \\
\hline \multirow{2}{*}{ Agustus } & 1 & & 0,90 & 0,54 & $-0,35$ & Deficit & 0,61 & \\
\hline & 2 & . & 0,70 & 0,69 & $-0,01$ & Deficit & 0.99 & \\
\hline \multirow{2}{*}{ September } & 1 & & 0,68 & 0,66 & $-0,03$ & Deficit & 0.96 & \\
\hline & 2 & & 0,68 & 0,63 & $-0,06$ & Deficit & 0.92 & \\
\hline \multirow{2}{*}{ Oktober } & 1 & & 0,14 & 0,57 & 0,43 & Surplus & 1,00 & \\
\hline & 2 & & 0,00 & 1.22 & 1,22 & Surplus & 1,00 & \\
\hline
\end{tabular}

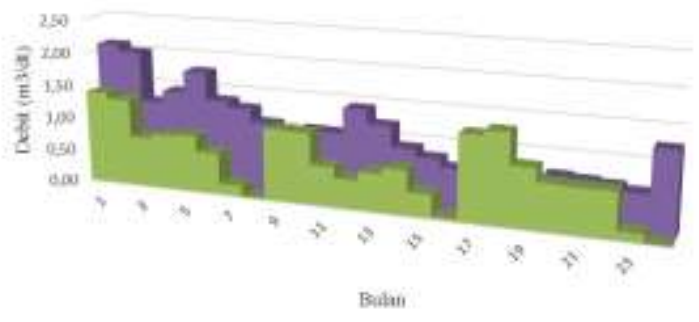

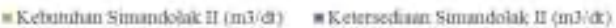

Gambar 4 Grafik Neraca Air Pola Tanam Padi-Padi-padi

Secara teoritis untuk mengatasi kekurangan debit untuk memenuhi kebutuhan tanaman, ada tiga alternatif yang dapat dipilih, yaitu mengurangi luas daerah irigasi yang akan dialiri, mengubah pola tanam dan rotasi teknis golongan. Pada penelitian ini digunakan rotasi teknis golongan untuk mengatasi kekurangan air pada sawah (deficit)

\subsection{Pembagian Golongan}

Pemberian air dengan golongan berguna untuk mengurangi kebutuhan puncak air irigasi [1]. Cara ini digunakan apabila jumlah air yang tersedia sangat terbatas, dan kebutuhan air tanaman khususnya pada saat pengelolaan lahan sangat besar. Masa tanam dilakukan dengan cara bertahap yang dikelompokkan dari satu petak tersier kepetak lain atau disebut sebagai penggolongan. Pembagian satu daerah irigasi idealnya terdiri dari tiga sampai 5 golongan dengan jarak masa tanam dua sampai tiga minggu.

Pembagian golongan DI Simandolak II

Golongan A : $152,40 \mathrm{Ha}$

Golongan B : $146,40 \mathrm{Ha}$

Golongan C : $\quad 391,30 \mathrm{Ha}$

\subsection{Kebutuhan air penggolongan}

Pemberian air dengan golongan berguna untuk mengurangi kebutuhan puncak air irigasi [1]. Pembagian satu daerah irigasi idealnya terdiri dari tiga sampai 5 golongan dengan jarak masa tanam dua sampai tiga minggu. Pembagian ini dilakukan dengan pertimbangan kesatuan sistem bangunan, wilayah administrative, dan wilayah pengairan (juru pintu air, juru pengairan, dan $\mathrm{P} 3 \mathrm{~A}$ )

Rekapitulasi kebutuhan air untuk tiap DI dan pola tanam dapat dilihat pada Tabel 7 dan Tabel 8 berikut

Tabel 7 Kebutuhan air total kondisi penggolongan pola tanam padi-bera-bera

No Bulan Periode Kebutuhan No Bulan Periode Kebutuhan

\begin{tabular}{|c|c|c|c|c|c|c|c|}
\hline \multirow{2}{*}{1} & \multirow{2}{*}{ Nov } & I & 0,31 & \multirow{2}{*}{7} & \multirow{2}{*}{ Mei } & I & 0,00 \\
\hline & & II & 0,57 & & & II & 0,00 \\
\hline \multirow{2}{*}{2} & \multirow{2}{*}{ Des } & I & 1,29 & \multirow{2}{*}{8} & \multirow{2}{*}{ Jun } & I & 0,00 \\
\hline & & II & 1,22 & & & II & 0,00 \\
\hline \multirow{2}{*}{3} & \multirow{2}{*}{ Jan } & I & 0,87 & \multirow{2}{*}{9} & \multirow{2}{*}{ Jul } & I & 0,00 \\
\hline & & II & 0,65 & & & II & 0,00 \\
\hline \multirow{2}{*}{4} & \multirow{2}{*}{ Feb } & I & 0,55 & \multirow{2}{*}{10} & \multirow{2}{*}{ Agu } & I & 0,00 \\
\hline & & II & 0,40 & & & II & 0,00 \\
\hline \multirow{2}{*}{5} & \multirow{2}{*}{ Mar } & I & 0,06 & \multirow{2}{*}{11} & \multirow{2}{*}{ Sep } & I & 0,00 \\
\hline & & II & 0,00 & & & II & 0,00 \\
\hline \multirow{2}{*}{6} & \multirow{2}{*}{ Apr } & I & 0,00 & \multirow{2}{*}{12} & \multirow{2}{*}{ Okt } & I & 0,00 \\
\hline & & II & 0,00 & & & II & 0,00 \\
\hline
\end{tabular}

Tabel 8 Kebutuhan air total kondisi penggolongan pola tanam padi-padi-padi

\begin{tabular}{|c|c|c|c|c|c|c|c|}
\hline No & Bulan & Periode & $\begin{array}{l}\text { Kebutuhan } \\
\text { Air (m3/dt) }\end{array}$ & No & Bulan & Periode & $\begin{array}{l}\text { Kebutuhan } \\
\text { Air (m3/dt) }\end{array}$ \\
\hline \multirow{2}{*}{1} & \multirow{2}{*}{ Nov } & I & 0,43 & \multirow{2}{*}{7} & \multirow{2}{*}{ Mei } & I & 0,59 \\
\hline & & II & 0,57 & & & II & 0,70 \\
\hline \multirow{2}{*}{2} & \multirow{2}{*}{ Des } & I & 1,29 & \multirow{2}{*}{8} & \multirow{2}{*}{ Jun } & $\mathrm{I}$ & 0,69 \\
\hline & & II & 1,22 & & & II & 0,43 \\
\hline \multirow{2}{*}{3} & \multirow{2}{*}{ Jan } & I & 0,87 & \multirow{2}{*}{9} & \multirow{2}{*}{ Jul } & I & 0,48 \\
\hline & & II & 0,65 & & & II & 0,69 \\
\hline \multirow{2}{*}{4} & \multirow{2}{*}{ Feb } & I & 0,55 & \multirow{2}{*}{10} & \multirow{2}{*}{ Agu } & I & 1,28 \\
\hline & & II & 0,40 & & & II & 0,98 \\
\hline \multirow{2}{*}{5} & \multirow{2}{*}{ Mar } & I & 0,29 & \multirow{2}{*}{11} & \multirow{2}{*}{ Sep } & I & 0,70 \\
\hline & & II & 0,46 & & & II & 0,71 \\
\hline \multirow{2}{*}{6} & \multirow{2}{*}{ Apr } & I & 1,00 & \multirow{2}{*}{12} & \multirow{2}{*}{ Okt } & I & 0,52 \\
\hline & & II & 0,74 & & & II & 0,46 \\
\hline
\end{tabular}




\subsection{Neraca Air Penggolongan}

Tabel 9 Neraca air penggolongan pola tanam padi-berabera

\begin{tabular}{|c|c|c|c|c|c|c|c|c|}
\hline Bulan & Periode & MT & $\begin{array}{c}\text { Kebutuhan } \\
\text { m3/dt }\end{array}$ & $\begin{array}{c}\text { Ketersediaan Air Q } \\
\text { Andalan } 80 \% \\
\text { m3/dt }\end{array}$ & $\begin{array}{c}\text { Imbang } \\
\text { Air }\end{array}$ & Kondisi & Faktor K & $\begin{array}{l}\text { Rata-rata } \\
\text { Faktor K }\end{array}$ \\
\hline \multirow{2}{*}{ November } & 1 & \multirow{8}{*}{ MT 1} & 0,31 & 2,07 & 1,76 & Surplus & 1,00 & \multirow{8}{*}{0,99} \\
\hline & 2 & & 0,57 & 1,97 & 1,41 & Surplus & 1,00 & \\
\hline \multirow{2}{*}{ Desember } & 1 & & 1,29 & 1,23 & $-0,06$ & Deficit & 0,95 & \\
\hline & 2 & & 1,22 & 1,41 & 0,19 & Surplus & 1,00 & \\
\hline \multirow{2}{*}{ Januari } & 1 & & 0,87 & 1,74 & 0,88 & Surplus & 1,00 & \\
\hline & 2 & & 0,65 & 1,33 & 0,68 & Surplus & 1,00 & \\
\hline \multirow{2}{*}{ Februari } & 1 & & 0,55 & 1,24 & 0,70 & Surplus & 1,00 & \\
\hline & 2 & & 0,40 & 1,05 & 0,65 & Surplus & 1,00 & \\
\hline \multirow{2}{*}{ Maret } & 1 & \multirow{8}{*}{ MT 2} & 0,06 & 0,84 & 0,79 & Surplus & 1,00 & \multirow{8}{*}{1,00} \\
\hline & 2 & & 0,00 & 1,01 & 1,01 & Surplus & 1,00 & \\
\hline \multirow{2}{*}{ April } & 1 & & 0,00 & 1,00 & 1,00 & Surplus & 1,00 & \\
\hline & 2 & & 0,00 & 1,39 & 1,39 & Surplus & 1,00 & \\
\hline \multirow{2}{*}{ Mei } & 1 & & 0,00 & 1,18 & 1,18 & Surplus & 1,00 & \\
\hline & 2 & & 0,00 & 0,88 & 0,88 & Surplus & 1,00 & \\
\hline \multirow{2}{*}{ Juni } & 1 & & 0,00 & 0,77 & 0,77 & Surplus & 1,00 & \\
\hline & 2 & & 0,00 & 0,64 & 0,64 & Surplus & 1,00 & \\
\hline \multirow{2}{*}{ Juli } & 1 & & 0,00 & 0,56 & 0,56 & Surplus & 1,00 & \multirow{8}{*}{1,00} \\
\hline & 2 & & 0,00 & 0,55 & 0,55 & Surplus & 1,00 & \\
\hline \multirow{3}{*}{ Agustus } & 1 & & 0,00 & 0,54 & 0,54 & Surplus & 1,00 & \\
\hline & 2 & & 0,00 & 0,69 & 0,69 & Surplus & 1,00 & \\
\hline & 1 & MT 3 & 0,00 & 0,66 & 0,66 & Surplus & 1,00 & \\
\hline September & 2 & & 0,00 & 0,63 & 0,63 & Surplus & 1,00 & \\
\hline \multirow{2}{*}{ Oktober } & 1 & & 0,00 & 0,57 & 0,57 & Surplus & 1,00 & \\
\hline & 2 & & 0,00 & 1,22 & 1,22 & Surplus & 1,00 & \\
\hline
\end{tabular}

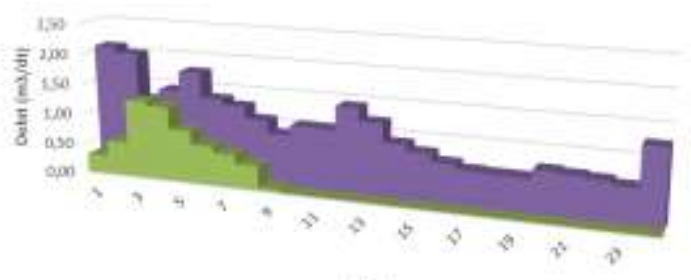

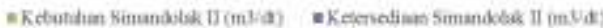

Gambar 5 Grafik neraca air pola tanam padi-bera-bera

\subsection{Penjadwalan dan Pembagian Rotasi}

Metode rotasi irigasi yaitu cara pemberian air pada saluran utama atau saluran tersier menggunakan dengan waktu tertentu apabila debit ketersediaan tidak mencukupi debit yang diperlukan yang dinyatakan dengan faktor $\mathrm{K}$ [3].

Jika persediaan air mencukupi, maka faktor $\mathrm{K}$ $=1$ dimana rencana pemberian dan pembagian air sesuai dengan rencana awal pemberian dan pembagian air. Sedangkan jika persediaan air kurang, maka faktor $\mathrm{K}<1$ dan pemberian serta pembagian air diprioritaskan untuk pemenuhan kebutuhan air beberapa petak selanjutnya dirotasikan sesuai dengan
Tabel 10 Neraca air penggolongan pola tanam padi-padipadi

\begin{tabular}{|c|c|c|c|c|c|c|c|c|}
\hline Bulan & Periode & MT & $\begin{array}{c}\text { Kebutuhan } \\
\text { m3/dt }\end{array}$ & $\begin{array}{c}\text { Ketersediaan Air Q } \\
\text { Andalan } 80 \% \\
\text { m3/dt }\end{array}$ & $\begin{array}{c}\text { Imbang } \\
\text { Air }\end{array}$ & Kondisi & Faktor K & $\begin{array}{l}\text { Rata-rata } \\
\text { Faktor K }\end{array}$ \\
\hline \multirow{2}{*}{ November } & 1 & \multirow{8}{*}{ MT 1} & 0,43 & 2,07 & 1,64 & Surplus & 1,00 & \multirow{8}{*}{0,99} \\
\hline & 2 & & 0,57 & 1,97 & 1,41 & Surplus & 1,00 & \\
\hline \multirow{2}{*}{ Desember } & 1 & & 1,29 & 1,23 & $-0,06$ & Deficit & 0,95 & \\
\hline & 2 & & 1,22 & 1,41 & 0,19 & Surplus & 1,00 & \\
\hline \multirow{2}{*}{ Januari } & 1 & & 0,87 & 1,74 & 0,88 & Surplus & 1,00 & \\
\hline & 2 & & 0,65 & 1,33 & 0,68 & Surplus & 1,00 & \\
\hline \multirow{2}{*}{ Februari } & 1 & & 0,55 & 1,24 & 0,70 & Surplus & 1,00 & \\
\hline & 2 & & 0,40 & 1,05 & 0,65 & Surplus & 1,00 & \\
\hline \multirow{2}{*}{ Maret } & 1 & \multirow{8}{*}{ MT 2} & 0,29 & 0,84 & 0,55 & Surplus & 1,00 & \multirow{8}{*}{1,00} \\
\hline & 2 & & 0,46 & 1,01 & 0,54 & Surplus & 1,00 & \\
\hline \multirow{2}{*}{ April } & 1 & & 1,00 & 1,00 & 0,01 & Surplus & 1,00 & \\
\hline & 2 & & 0,74 & 1,39 & 0,66 & Surplus & 1,00 & \\
\hline \multirow{2}{*}{ Mei } & 1 & & 0,59 & 1,18 & 0,59 & Surplus & 1,00 & \\
\hline & 2 & & 0,70 & 0,88 & 0,18 & Surplus & 1,00 & \\
\hline \multirow{2}{*}{ Juni } & 1 & & 0,69 & 0,77 & 0,07 & Surplus & 1,00 & \\
\hline & 2 & & 0,43 & 0,64 & 0,21 & Surplus & 1,00 & \\
\hline \multirow{2}{*}{ Juli } & 1 & & 0,48 & 0,56 & 0,08 & Surplus & 1,00 & \multirow{8}{*}{0,84} \\
\hline & 2 & & 0,69 & 0,55 & $-0,14$ & Deficit & 0,79 & \\
\hline \multirow{2}{*}{ Agustus } & 1 & & 1,28 & 0,54 & $-0,73$ & Deficit & 0,43 & \\
\hline & 2 & & 0,98 & 0,69 & $-0,29$ & Deficit & 0,70 & \\
\hline \multirow{2}{*}{ September } & 1 & MIIJ & 0,70 & 0,66 & $-0,04$ & Deficit & 0,94 & \\
\hline & 2 & & 0,71 & 0,63 & $-0,08$ & Deficit & 0,88 & \\
\hline \multirow{2}{*}{ Oktober } & 1 & & 0,52 & 0,57 & 0,05 & Surplus & 1,00 & \\
\hline & 2 & & 0,46 & 1,22 & 0,76 & Surplus & 1,00 & \\
\hline
\end{tabular}

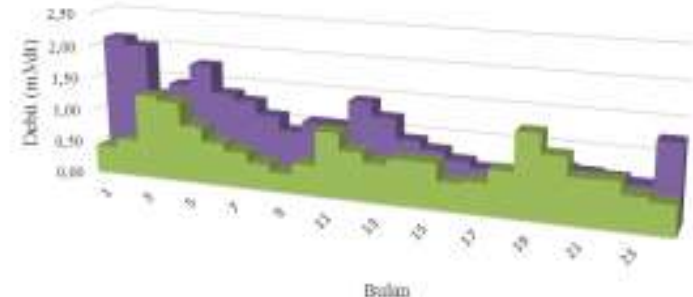

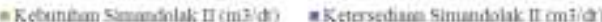

Gambar 6 Grafik neraca air pola tanam padi-padi-padi

jadwal pembagian dan pemberian air irigasi sesuai masa pertumbuhan tanaman. Persamaan yang digunakan untuk menghitung faktor K yaitu :

$$
\mathrm{K}=\frac{\text { Debit yang tersedia }}{\text { Debit yang dibutuhkan }}
$$

Penjadwalan dan pembagian rotasi hanya dilakukan untuk musim tanam yang mengalami kekurangan air (deficit) setelah dilakukan penggolongan dan dianalisa menggunakan neraca air menggunakan periode gilir 15 harian berpedoman pada periode yang digunakan dalam perhitungan kebutuhan dan ketersediaan air selama 24 jam

Tabel 11 Jadwal pemberian air irigasi pola tanam padi-bera-bera

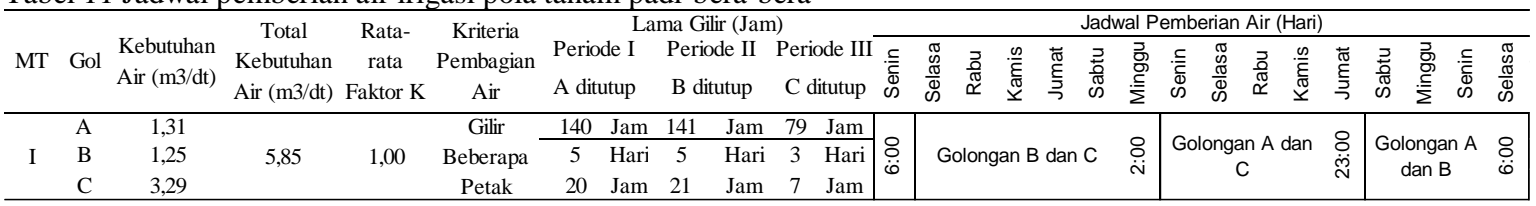


Tabel 12 Jadwal pemberian air irigasi pola tanam padi-padi-padi

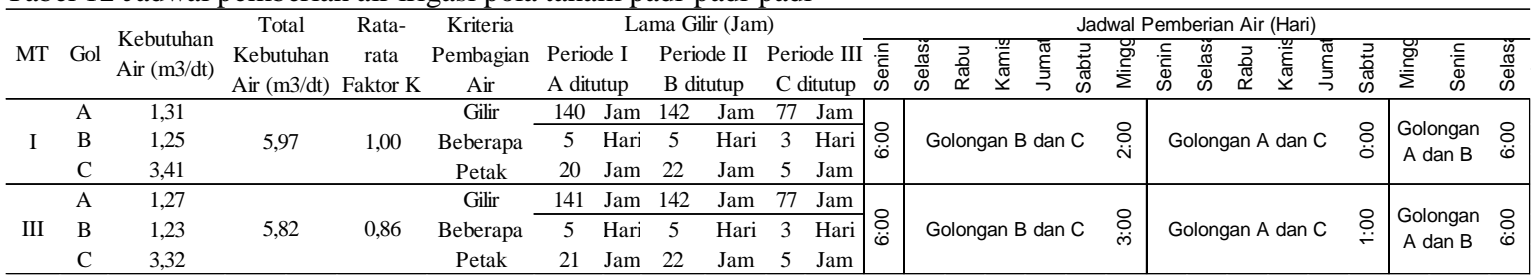

Berdasarkan analisa rotasi jika periode gilir yang digunakan semakin panjang, maka akan semakin lama waktu yang diperlukan tanaman selanjutnya untuk diairi. Pada dasarnya tanaman memiliki fase dalam pertumbuhannya, dimana jumlah air dapat dikurangi dan tanaman masih dapat mentoleransi kekurangan air. Waktu mengunggu air yang terlalu lama akan berakibat pada kematian tanaman. Sementara jika semakin pendek periode gilir yang digunakan, maka semakin pendek pula waktu operasional bukaan pintu. Akibatnya operator pintu semakin sering untuk mengatur buka dan tutup pintu air yang mengaliri sawah

\subsection{Persentase Pemanfaatan Rotasi dan Penggolongan Terhadap Debit \\ Ketersediaan}

Analisa ini digunakan untuk membuktikan persentase keberhasilan rotasi irigasi. Data yang ada dikonversi dalam bentuk satuan volume $\left(\mathrm{m}^{3}\right)$.

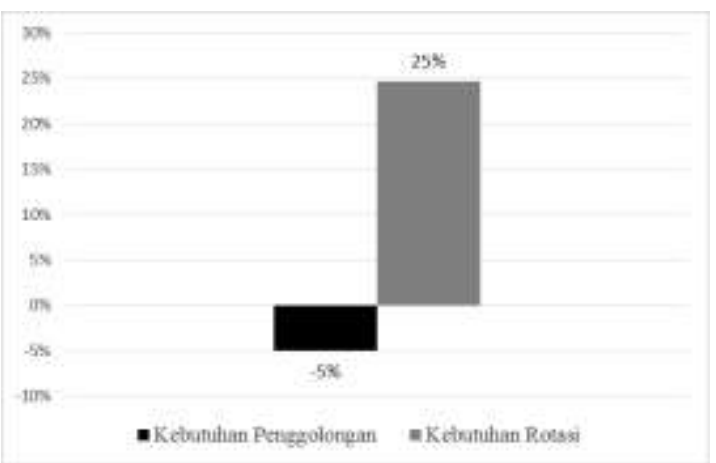

Gambar 7 Perbandingan persentase pemanfaatan penggolongan dan rotasi terhadap ketersediaan pola tanam padi-bera-bera MT I

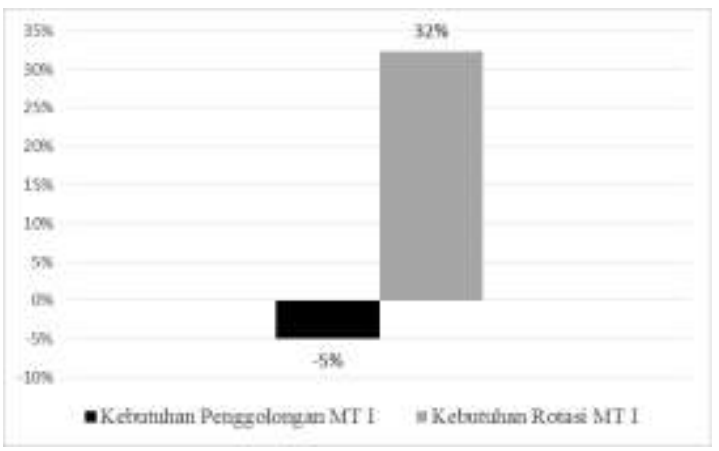

Gambar 8 Perbandingan persentase pemanfaatan penggolongan dan rotasi terhadap ketersediaan pola tanam padi-padi-padi MT I

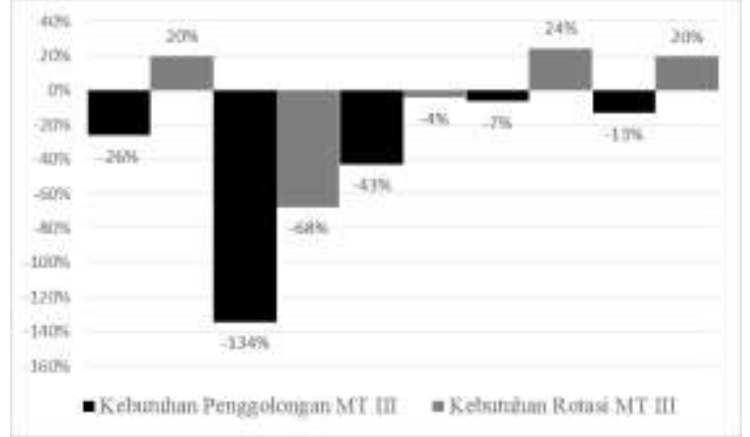

Gambar 9 Perbandingan persentase pemanfaatan penggolongan dan rotasi terhadap ketersediaan pola tanam padi-padi-padi MT III

\section{KESIMPULAN}

1. Hasil rekapitulasi data ketersediaan air periode setengah bulanan diperoleh besarnya debit andalan $80 \%$ pada DAS Simandolak II dengan debit tertinggi terjadi pada bulan November periode I sebesar $2,07 \mathrm{~m}^{3} / \mathrm{dt}$ dan debit terendah terjadi pada bulan Agustus periode I sebesar 0,54 $\mathrm{m}^{3} / \mathrm{dt}$

2. Nilai kebutuhan air tertinggi terjadi pada DI Simandolak II untuk tiap pola tanam bulan November periode I sebesar 1,40 $\mathrm{m}^{3} / \mathrm{dt}$ menggunakan luasan total, sementara untuk kebutuhan air secara golongan diperoleh nilai sebesar $0,31 \mathrm{~m}^{3} / \mathrm{dt}$

3. Hasil analisis neraca air didapat kekurangan air terbanyak terjadi pada pola tanam padi-padi-padi untuk tiap masa tanam pada DI Simandolak II sebanyak 8 periode deficit.

4. Sistem rotasi irigasi dapat diterapkan secara efektif di lapangan, jika :

1. Komponen irigasi dan pintu air yang ada masih dapat digunakan dan berfungsi baik

2. Adanya operator yang bertugas untuk membuka dan menutup pintu air secara berkala sesuai rencana penjadwalan dan pemberian air

5. Persentase peningkatan volume terbesar terjadi pada Simandolak I musim tanam ketiga untuk pola tanam padi-padi-padi sebesar $66 \%$

\section{DAFTAR PUSTAKA}

[1] Anonim. (1986). Kriteria Perencanaan Jaringan Irigasi KP-01. Bandung: Ditjen. Pengairan Dep. PU Galang Persada. 
[2] Anonim. (2017). Penyusunan Penilaian

Kinerja dan Penyusunan AKNOP D.I.

Simandolak-Pangean Kab, Kuantan Singingi.

Pekanbaru: Balai Wilayah Sungai Sumatera

III.

[3] Huda, M. N., Harisuseno, D., \& Priyantoro, D. (2012). Kajian Sistem Pemberian Air Irigasi Sebagai Dasar Penyusunan Jadwal Rotasi Pada Daerah Irigasi Tumpang Kabupaten Malang. Jurnal Teknik Pengairan, 3(2), 221-229.

[4] Jannata, Abdullah, S., \& Haji Priyati, A. (2015). Analisa Kinerja Pengelolaan Irigasi Di Daerah Irigasi Lemor, Kabupaten Lombok Timur, Nusa Tenggara Barat. Jurnal Ilmiah Rekayasa Pertanian Dan Biosistem, 3(1), 146-152.

[5] Saleh, E. (2010). Studi Konflik Air Irigasi dan Alternatif Penyelesaiannya di Daerah Irigasi Kelingi Sumatera Selatan. Jurnal Keteknikan Pertanian, 24(1), 39-43.

[6] Thohir, M., Sayekti, R. W., \& Ismoyo, M. J. (2017). Studi Pola Pemberian Air Irigasi Berdasarkan Faktor Jarak Sebagai Upaya Pemenuhan Kebutuhan Air Di D . I Jeruk Taman Kabupaten Probolinggo. Jurnal Teknik Pengairan. 